\title{
Occurrence of Palygorskite in Soils of Ecija (Spain)
}

\author{
J. L. Pérez-Rodriguez, ${ }^{\mathrm{A}}$ C. Maqueda ${ }^{\mathrm{B}}$ and E. Morillo ${ }^{\mathrm{B}}$ \\ A Instituto de Ciencias de Materiales, Aptdo 1052, 41080-Sevilla, Spain. \\ B Instituto de Recursos Naturales y Agrobiología, Aptdo 1052, \\ 41080 -Sevilla, Spain.
}

\section{Abstract}

Palygorskite has been characterized in soils classified as typic argixerolls, located in an extensive Quaternary zone in the north of Seville (Spain), where the geological and climatic conditions suggest its genesis. The soils contain a $\mathrm{Ck}$ horizon which has different textural characteristics to the other horizons in the profiles. The presence of large white calcareous nodules and cristobalite is the principal difference between them.

The formation of palygorskite at textural discontinuities is in agreement with the characteristics of these soils. Under the present conditions of the soils $(\mathrm{pH}$, magnesium and silicon concentration and soluble salts), the alteration of palygorskite to smectite is suggested.

The sporadic nucleation of large fibres of palygorskite on silica crystal suggests that this latter mineral could provide the necessary silicon for palygorskite formation.

\section{Introduction}

Palygorskite is widely distributed in many arid and semi-arid soils and sediments. Although some years ago palygorskite was considered a relatively rare mineral in soils, recently an increasing number of reports of its occurrence in soils have appeared (Zelazny and Calhoun 1977; Singer and Galan 1984).

Palygorskite has been reported in soils from many countries in the Near and Middle East, from northern and southern Africa, North and Central America, Australia and even Europe. Spain has the world's currently known reserves of sepiolite-palygorskite minerals. Their genesis has been studied by various authors (Galan and Castillo 1984; Galan 1987; Leguey et al. 1984; Lopez Galindo 1987; Ruiz Cruz et al. 1988). However, the occurrence of palygorskite in Spanish soils is relatively scarce (Sanchez Camazano and Garcia Rodriguez 1971; Sanchez Camazano et al. 1984). Palygorskite has been considered a relatively rare mineral as it is rarely a dominant mineral in soils and its identification is principally made by X-ray diffraction. The major X-ray reflection used for the identification of palygorskite is likely to be masked by that of illite (both minerals normally appear in soil together). Many of the reports on palygorskite consider that this mineral has been derived from the sedimentary parent material and, due to its rapid weathering, is eliminated from soil profiles, being found in soils only under arid conditions. However, in many other soils there is no evidence for palygorskite having been inherited 
from the parent material, and it has been suggested that palygorskite had formed in the soil environment (Elprince et al. 1979; Singer 1984).

Singer (1984) considered that palygorskite formed 'in situ' can commonly be associated with one of the three following situations: (a) modern soils affected by rising ground water; $(b)$ soil formations with textural discontinuities; or $(c)$ pedogenic features, such as calcretes, crusts and caliches.

In many soils, a palygorskite-smectite relationship has been observed, and the transformation of one into the other has been discussed (Abtahi 1977; Yaalon and Wieder 1976; Elprince et al. 1979; Bigham et al. 1980; Lee et al. 1983; MacKenzie et al. 1984; Shadfan et al. 1985). Recently, Martin de Vidales et al. (1987) have suggested a pedogenic model in which palygorskite is produced by smectite weathering.

Table 1. Soil description (profile I)

Soil profile location: Ecija (Seville). Finca Alcorrin (Alcorrin Estate); Km. 2 Marchena road

\begin{tabular}{|c|c|c|}
\hline Horizon & Depth $(\mathrm{cm})$ & Description \\
\hline$A p$ & $0-30$ & $\begin{array}{l}\text { Dark reddish brown }(5 Y R 3 / 4) ; \\
\text { sandy loam; moderate to strong, } \\
\text { thick to very thick, crumb } \\
\text { structure; friable; porous; } \\
\text { permeable, calcareous; } \\
\text { moderately organic; a few } \\
\text { roots, medium biological } \\
\text { activity; some calcareous } \\
\text { concretions and gravels; } \\
\text { diffuse and smooth boundary }\end{array}$ \\
\hline$A B$ & $30-60$ & $\begin{array}{l}\text { Reddish brown (5YR4/4); clay; } \\
\text { moderate thick subangular } \\
\text { blocky structure; firm; } \\
\text { slightly porous; permeable; } \\
\text { calcareous; slightly organic; } \\
\text { little dense; small roots; fair } \\
\text { biological activity, some small } \\
\text { calcareous concretions and } \\
\text { gravels; gradual and smooth } \\
\text { boundary }\end{array}$ \\
\hline $\mathrm{Bk}$ & $60-80$ & $\begin{array}{l}\text { Yellowish red }(5 Y R 5 / 6) \text {; sandy } \\
\text { loam, moderate medium to thick } \\
\text { subangular blocky structure; } \\
\text { firm to friable; slightly porous; } \\
\text { permeable; very calcareous; } \\
\text { diffuse and smooth boundary }\end{array}$ \\
\hline $\mathrm{Ck}$ & $80-140$ & $\begin{array}{l}\text { Reddish yellow (5YR6/6); sandy } \\
\text { clay loam; moderate medium to } \\
\text { thick subangular blocky } \\
\text { structure; friable to firm; } \\
\text { slightly porous; very } \\
\text { calcareous; large white and hard } \\
\text { calcareous nodules }\end{array}$ \\
\hline
\end{tabular}



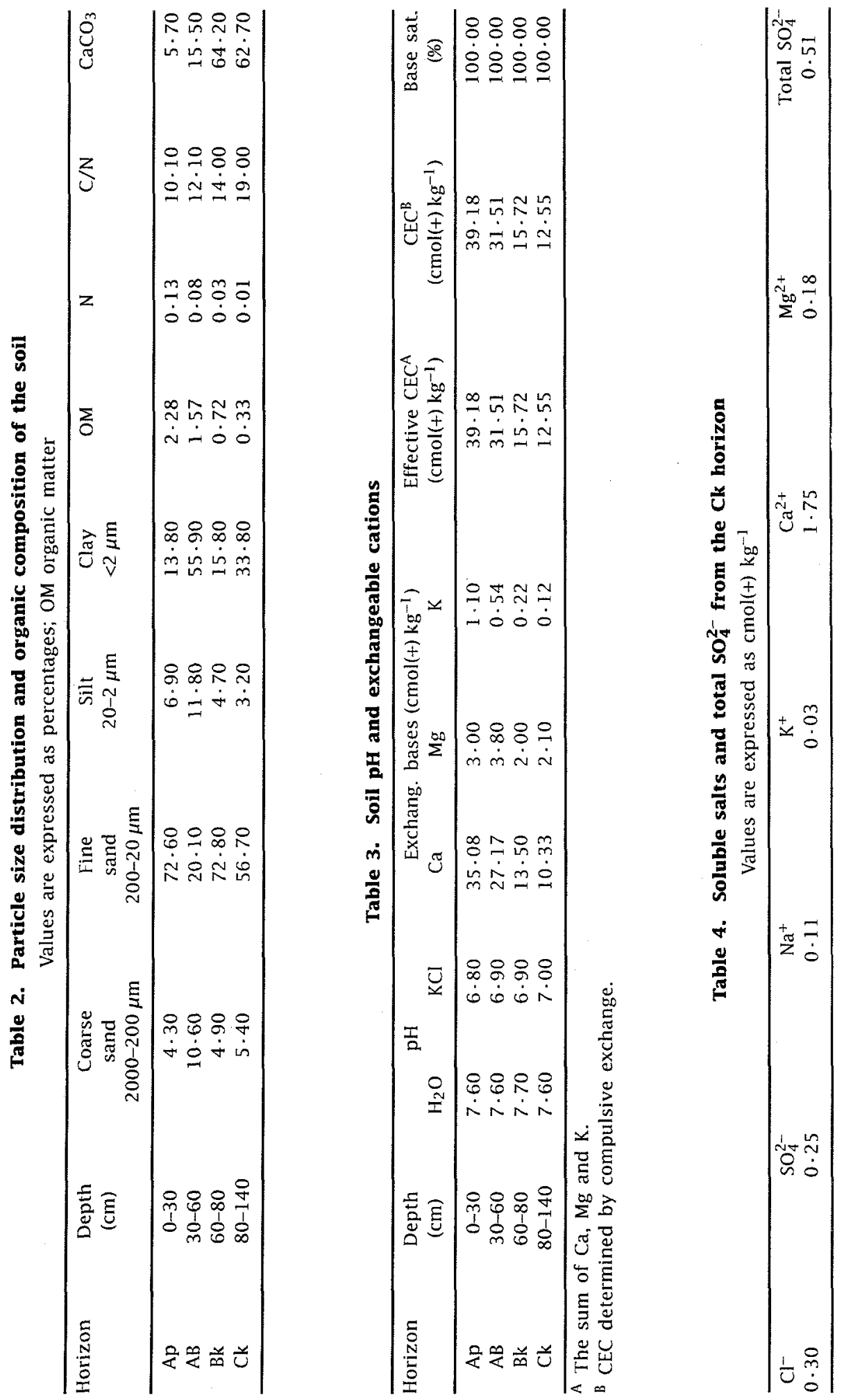
The aims of this study are: (a) to characterize palygorskite in an extensive Quaternary zone located in Ecija (in the north of Seville Province), where the geological, residual lagoon and climatic conditions suggest its genesis; (b) to follow the weathering sequences of this mineral; and $(c)$ to provide further information on the environmental conditions of palygorskite in soils and sediments in order to gain a better pedogenic knowledge.

\section{Materials and Methods}

\section{Soils and Location}

The soils used in this study are located near the city of Ecija in western Andalucia (Spain), on the Ecija-Marchena road. Rocks ranging from Miocene (Upper Tortonian) age to the present can be distinguished in this zone (IGME 1975). Miocene landslips have deposited exogenic materials of different ages from Triassic to Upper Miocene in an olistostrome. After the most recent landslips, autochthonous sediments were deposited, including Quaternary, gravels, red clays, dark brown limestone and silt, and true caliches, in some cases due to exudation and in others from the evolution of residual lagoons, within an extensive fluvial plain. The soils studied are located on Quaternary sediments.

The description of one soil is shown in Table 1 and particle size and chemical data are given in Tables 2-4. The soils have been classified as typic argixerolls.

\section{Methods}

Soil samples were dried and sieved $(<2 \mathrm{~mm})$ before analysis. Particle size analysis was carried out by the chain-hydrometer method (De Leenher et al. 1965). The pH was measured in a soil : water suspension of $1: 2.5$ and in $\mathrm{KCl}$ solution. Organic matter was determined by dichromate oxidations, and extractable bases and cation exchange capacity were determined by the ammonium acetate method at $\mathrm{pH} 7$.

$\mathrm{X}$-ray diffraction of powdered and oriented aggregates of clay fractions, pre-saturated with $\mathrm{Mg}^{2+}$, was performed with a Siemens D-500 X-ray diffractometer, using $\mathrm{Cu} \mathrm{K} \alpha$ radiation. Diffraction patterns of the samples were made before and after treatment with ethylene glycol and dimethysulfoxide, $\mathrm{K}^{+}$-saturated and heated at $110^{\circ} \mathrm{C}$. Differential thermal analysis (DTA) and thermogravimetric analysis (TG) were made in a Rigaku PTC-10A apparatus, using $40 \mathrm{mg}$ of sample and a heating rate of $12^{\circ} \mathrm{C} \mathrm{min}^{-1}$.

The chemical compositions were determined after dissolving the samples in $\mathrm{HF}_{1} \mathrm{HNO}_{3}$ and $\mathrm{HCl}$ in a Perkin-Elmer digestion bomb. The determination of $\mathrm{Si}, \mathrm{Al}, \mathrm{Fe}, \mathrm{Mg}$ and $\mathrm{Ca}$ was made by atomic absorption, and $\mathrm{Na}$ and $\mathrm{K}$ by flame emission.

The scanning electron microscopy study was made with an ISI apparatus, model SS40, and the dispersion energy of X-rays was measured by a Kevex analyser, model 800 . The transmission electron microscopy study was made with a Hitachi $\mathrm{H} 800-2$ apparatus.

Amorphous aluminosilicates were determined by extraction with $0.5 \mathrm{M} \mathrm{KOH}$ (Jackson 1969).

\section{Results}

The soils contain a $\mathrm{Ck}$ horizon (FAO 1988) which has different textural characteristics to the other horizons in the profiles. The presence of large white calcareous nodules in the $\mathrm{Ck}$ horizon is the principal difference between it and the other horizons.

The clay mineralogies of $A \mathrm{p}, \mathrm{AB}$ and $\mathrm{Bk}$ horizons (as deduced by $\mathrm{X}$-ray) are similar to one another (Fig. 1). The dominant mineral is illite, with appreciable amounts of kaolin, smectite in low proportion (though increasing down the profile), and some quartz. The shoulder towards smaller angles of the diffraction at $9.98 \AA$ is due to alteration of the illite. Electron microscopy confirmed that no other minerals were present.

The clay fractions of $\mathrm{Ck}$ horizons have different mineralogical compositions to those of the other horizons. The $\mathrm{X}$-ray diffraction patterns of $\mathrm{Ck}$ horizons 
from two different profiles are shown in Fig. 2. In the Mg-saturated sample, these horizons show a very strong reflection at $14.4 \AA$ that swells with ethylene glycol up to $17.65 \AA$, and collapses at $10.04 \AA$ after potassium saturation and heating at $110^{\circ} \mathrm{C}$. This reflection corresponds to smectite. There are also reflections at $10 \cdot 35 \AA$ and (one of less intensity at) $6 \cdot 36 \AA$, corresponding to 110

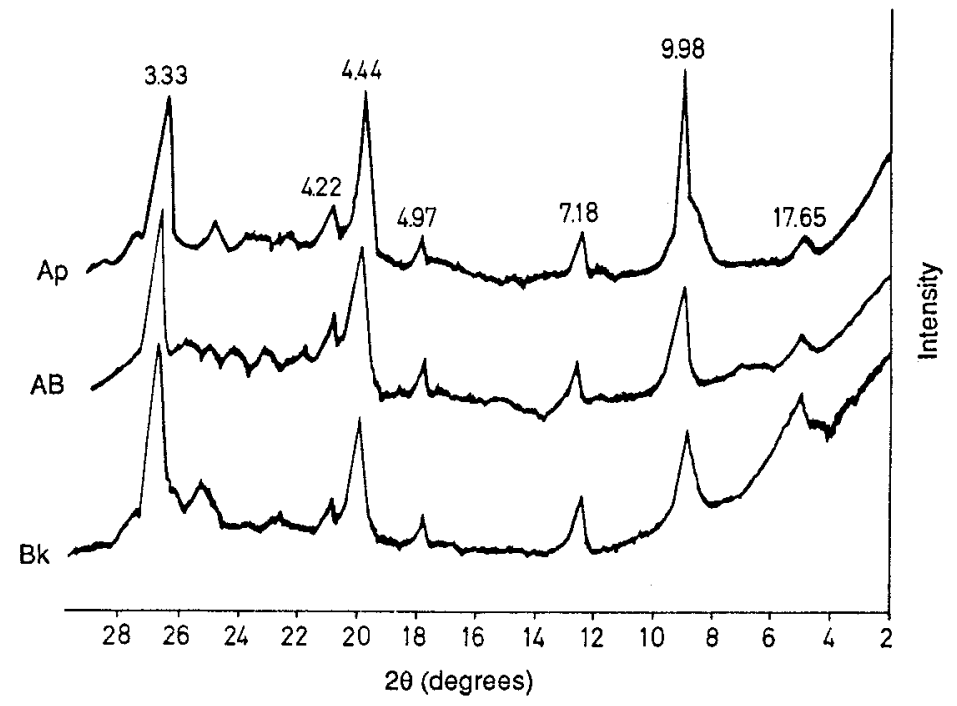

Fig. 1. X-ray diffraction pattern of clay fractions from $A p, A B$ and $B k$ horizons from profile I. The wavelength of each peak is given in units of $\dot{A}$.

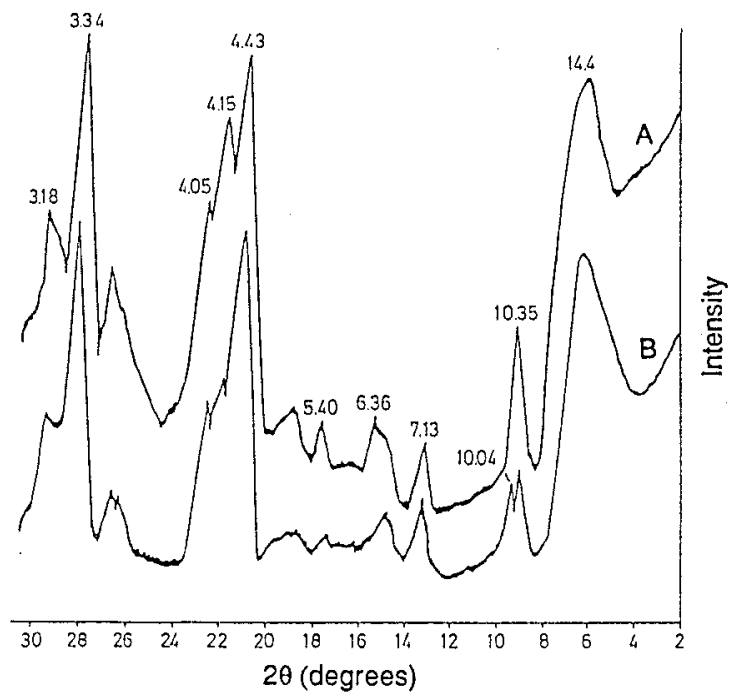

Fig. 2. X-ray diffraction patterns of $\mathrm{Ck}$ horizons from (A) profile I and (B) another profile in the same zone with similar characteristics. The wavelength of each peak is given in units of $A$. 
and 200 reflections of palygorskite respectively. Other characteristic reflections of the same mineral also appear at $5 \cdot 40 \AA$ (130), 4.43 $\AA$ (040), 3.18 $(400)$ and $2 \cdot 56 \AA(440)$. Reflections at $7 \cdot 13 \AA$ that swell to $11 \cdot 18 \AA$ after solvation with dimethylsulfoxide, and $10.04 \AA$ (with less intensity than at $10.35 \AA$ ) are attributed to kaolinite and illite respectively. Other reflections from these minerals are also present. Cristobalite is also shown, with a diffraction at $4.05 \AA$.

Quartz is probably also present, as the diffraction at $3 \cdot 34 \AA$ is very strong in relation to that at $10.04 \AA$. (The diffraction of quartz at $4.24 \AA$ is masked by the other diffractions.)

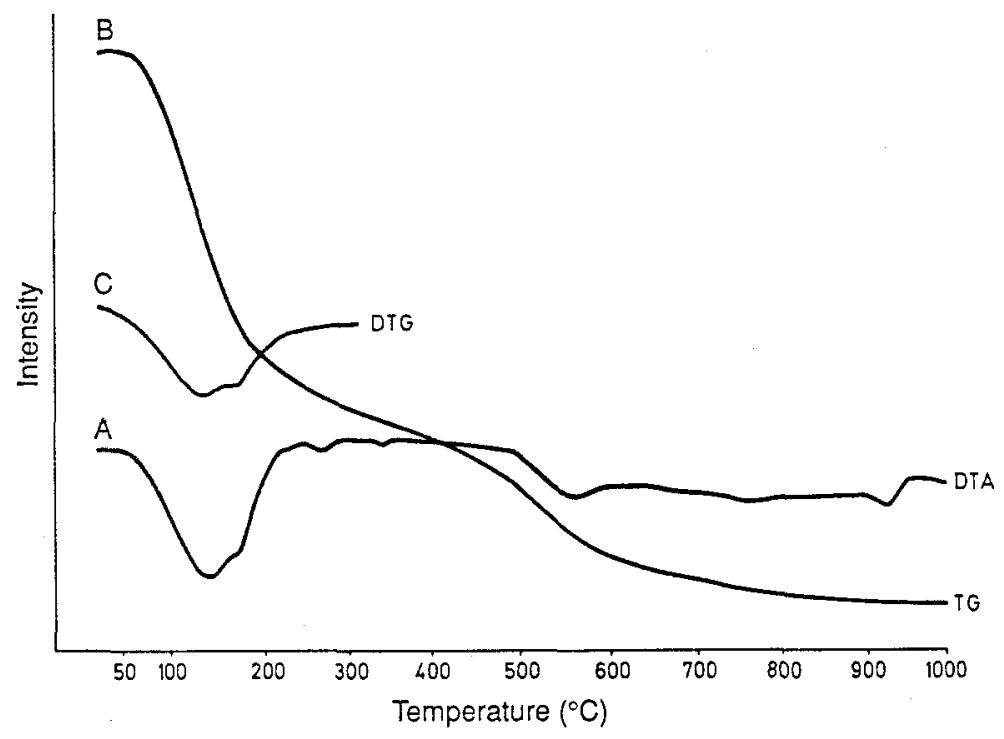

Fig. 3. Thermal analysis of a clay fraction from the $\mathrm{Ck}$ horizon from profile $\mathrm{I}$.

The DTA curve from the clay fraction of the $\mathrm{Ck}$ horizon (Fig. 3, curve A) shows an intense endothermic effect due to initial dehydration, with a maximum at about $150^{\circ} \mathrm{C}$. This effect takes place in two stages at 140 and $155^{\circ} \mathrm{C}$. The TG curve shows only one weight loss (curve $B$ ), but its derivative also shows two stages (curve C). Each stage corresponds to a different dehydration that may be attributed to smectite, although the second stage appears at a slightly lower temperature, and is somewhat more intense, than that given in the literature for this mixture (MacKenzie 1970). This could also be attributed to a mixture of minerals such as smectite and palygorskite; Pérez-Rodríguez (unpublished data) has found in mixtures of sepiolite-stevensite that the first endothermic effect at about $150^{\circ} \mathrm{C}$ has two stages corresponding to sepiolite and stevensite respectively.

The DTA curve (Fig. 3, curve A) shows an endothermic peak at about $285^{\circ} \mathrm{C}$, which is attributed to loss of coordinated water with magnesium from the palygorskite (Martín Vivaldi and Fenoll Hach-Ali 1970; Zelazny and Calhoun 1977). The other effects of the curves may be due to a mixture of the 


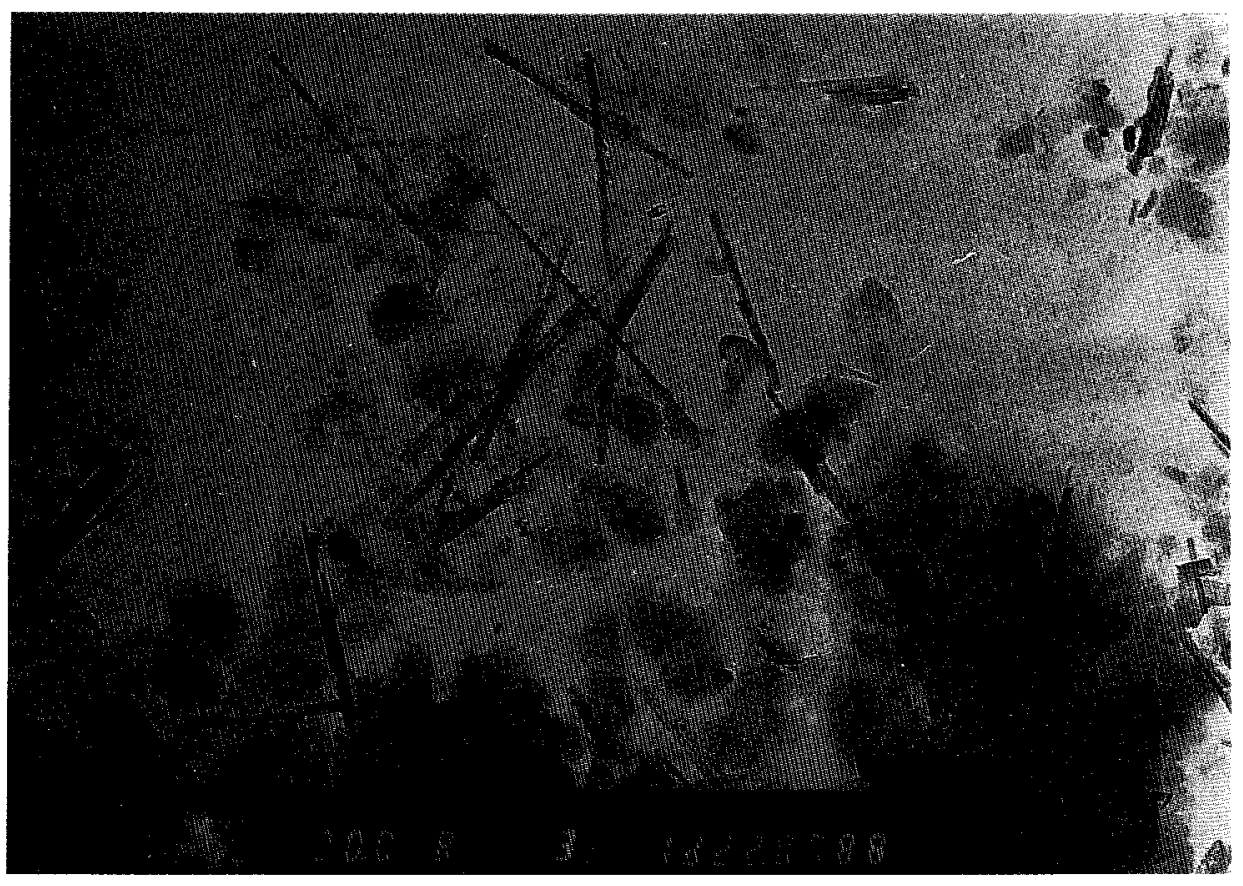

Fig. 4. Transmission electron micrograph of clays from the $\mathrm{Ck}$ horizon from profile I $(\times 20)$.

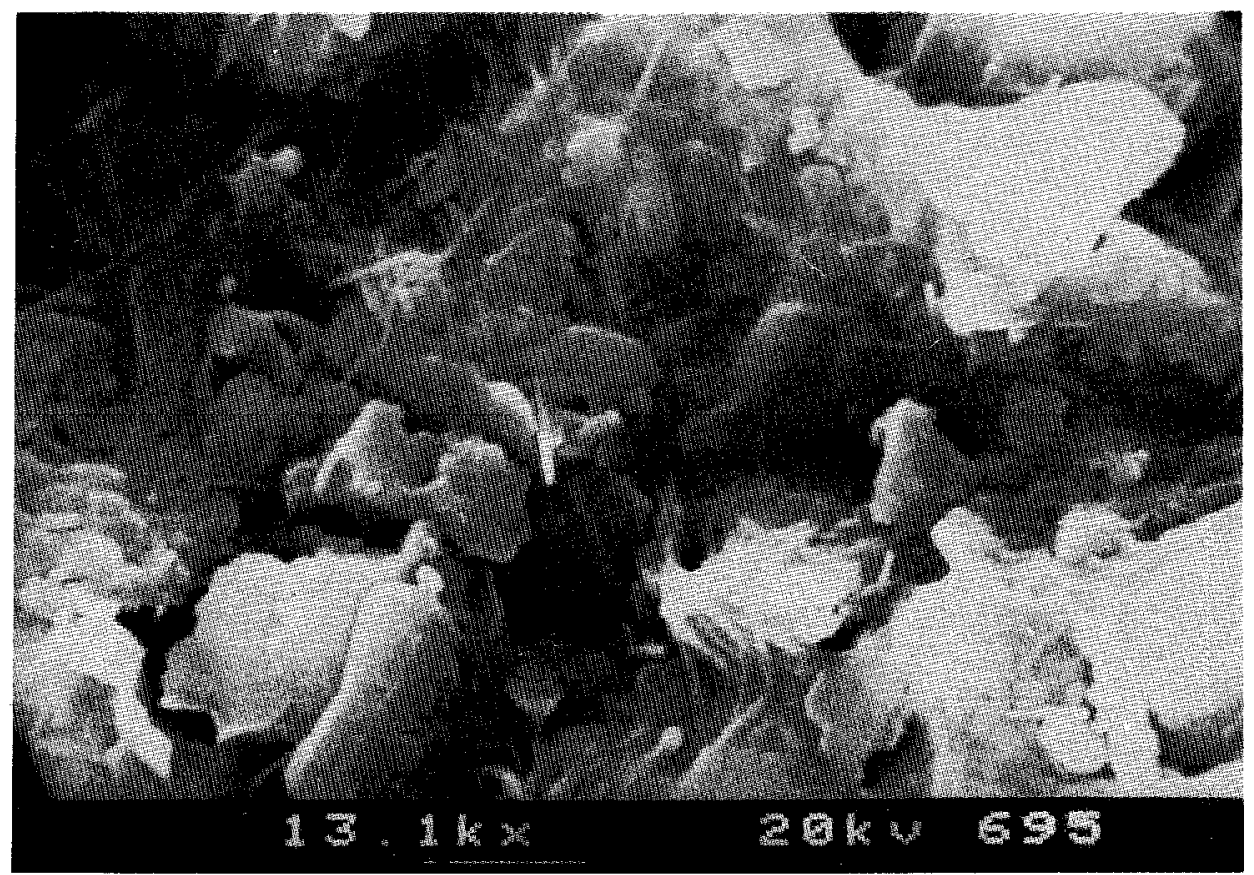

Fig. 5. Scanning electron micrograph of clays from the $\mathrm{Ck}$ horizon from profile $\mathrm{I}$. The longer scale marker $=1 \mu \mathrm{m}$. 


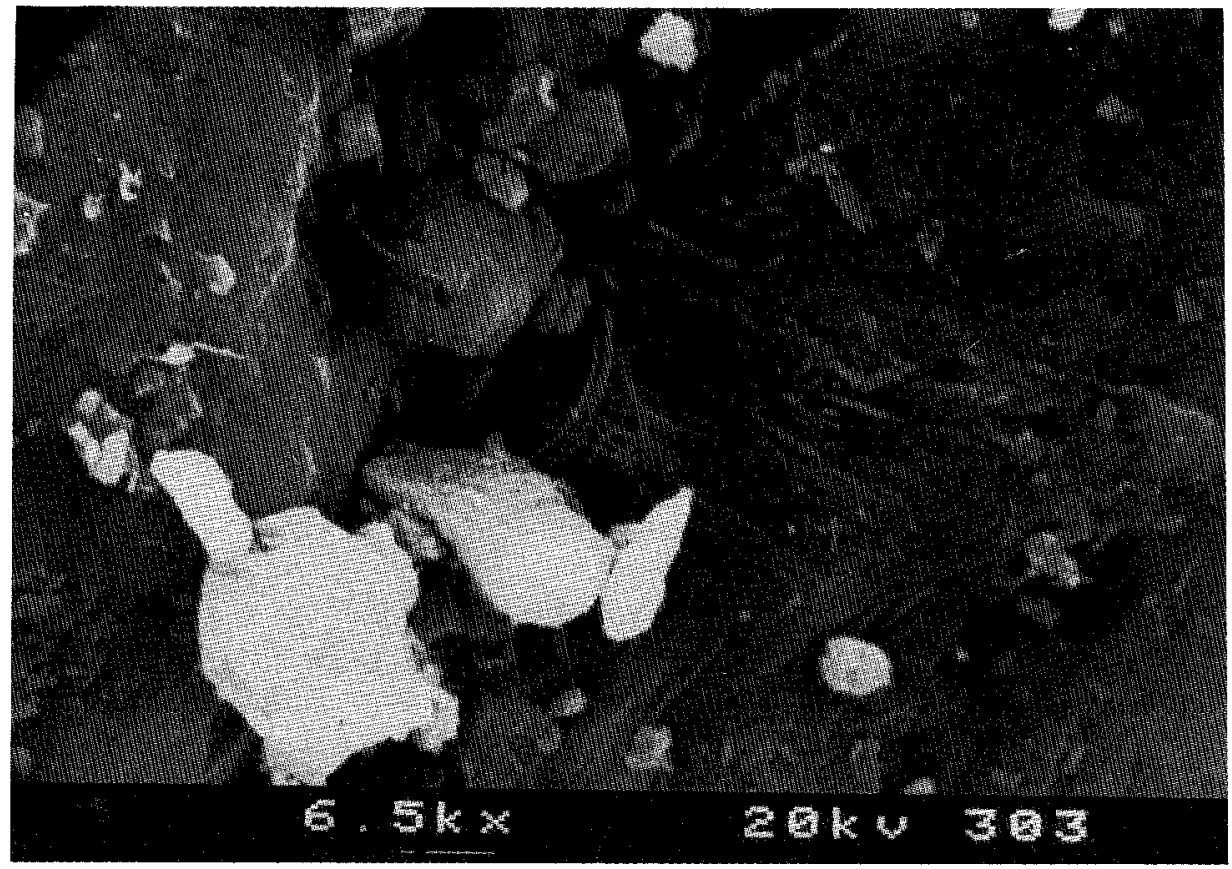

Fig. 6. Scanning electron micrograph of calcareous nodules from profile l. The longer scale marker $=10 \mu \mathrm{m}$.

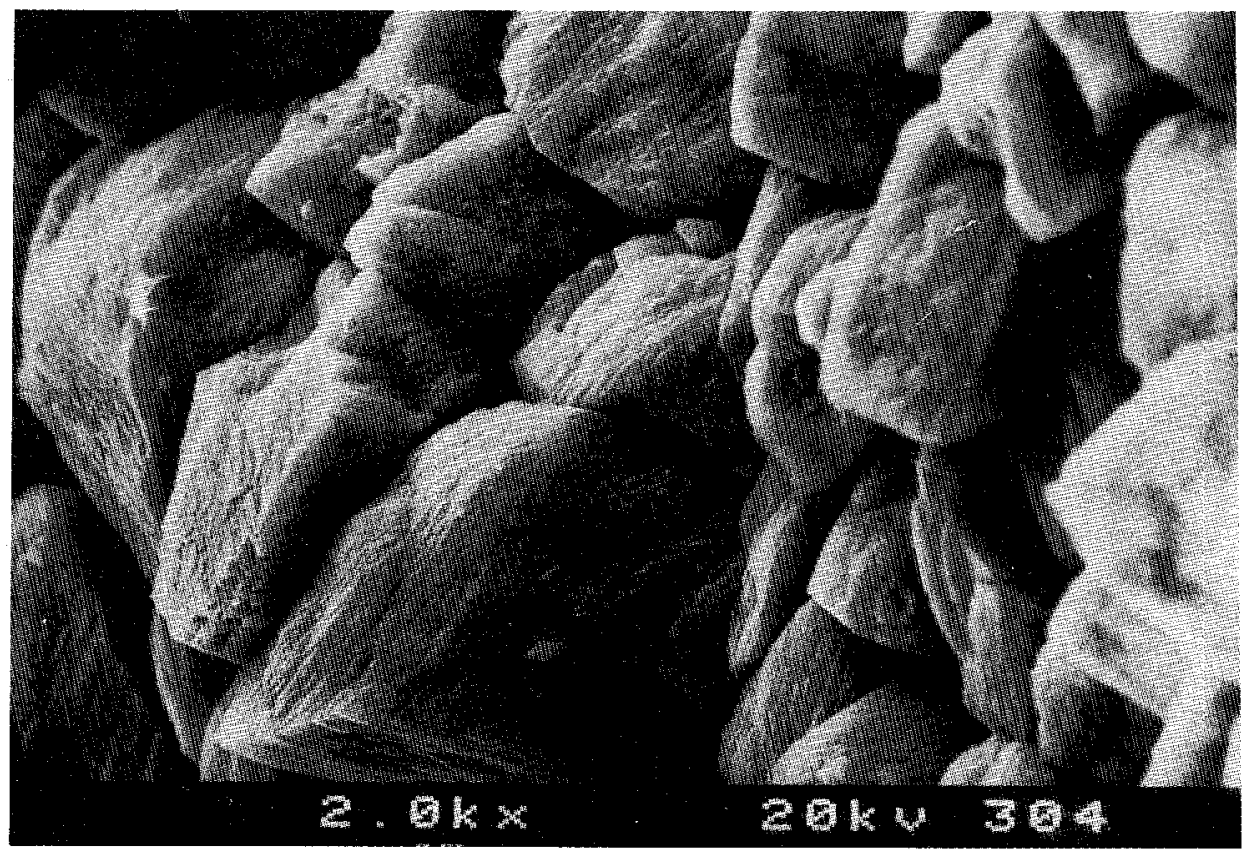

Fig. 7. Scanning electron micrograph of palygorskite coating quartz from profile I. Chemical analysis was by energy-dispersive $X$-ray of the substrate. The longer scale marker $=1 \mu \mathrm{m}$. 
minerals shown by X-ray diffraction. The other endothermic peak between 500 and $600^{\circ} \mathrm{C}$ and the exothermic peak at about $900^{\circ} \mathrm{C}$ can be attributed to soil smectite (González Garcia and Pérez Rodríguez 1970), and/or palygorskite. There may also be kaolinite included in these peaks.

The transmission electron micrographs showed an abundance of fibres which were assumed to be palygorskite (Fig. 4). Their proportion was higher in the $<0.2 \mu \mathrm{m}$ fraction than in the $0.2-2 \mu \mathrm{m}$ fraction. The higher concentration of palygorskite in the fine clay, rather than the coarse clay, has also been found by other authors (McLean et al. 1972; Shadfan and Dixon 1984; Shadfan et al. 1985). Scanning electron microscopy also shows the presence of fibres (Fig. 5), and chemical analysis made by $\mathrm{X}$-ray dispersive energy ( $\mathrm{Si}, \mathrm{Al}, \mathrm{Mg}$ ) is in agreement with the chemical composition of palygorskite.

There are hard white calcareous nodules in samples of fractions $<2 \mathrm{~mm}$ from the $\mathrm{Ck}$ horizon. X-ray diffraction shows that these are composed of calcite and a low proportion of quartz. Electron microscopy does not show palygorskite fibres on these nodules (Fig. 6). Pieces of yellowish marly limestone, composed of calcite, quartz and clay minerals, have also been collected from these fractions. The electron microscopy study shows palygorskite fibres and small, equidimensional, stubby particles that resemble cristobalite crystals. On the basis of the above association, it appears that palygorskite nucleates preferentially on inorganic crystalline substrates, such as sand and silt-sized calcite or gypsum crystals, although coatings of quartz, feldspar and hornblende have also been reported (Singer 1984). In these soils, palygorskite coating quartz has been also found, although sporadically (Fig. 7). Chemical analysis by energy-dispersive $\mathrm{X}$-rays shows that the substrate is constituted only of silicon.

\section{Discussion}

The characteristics of the $A p$ and $A B$ horizon in these soils are different from those of the other horizons (Table 1). Gravels are present, showing the influence of fluvial processes. The $\mathrm{Ck}$ horizon appears as a discontinuity throughout the profile; and is marked by the presence of both secondary calcite, in the form of nodules, and palygorskite. It seems that conditions leading to calcite nodule development are also favourable for the formation of palygorskite in situ. Millot et al. (1969), Lamouroux et al. (1973) and Singer and Norrish (1974) described soils with palygorskite below a calcareous crust horizon, in which the solum above the crust could be at an advanced stage of weathering. These soils have a lower proportion of $\mathrm{CaCO}_{3}$ in the upper horizon than in the lower horizon, showing a downward movement, with the $\mathrm{CaCO}_{3}$ deposited at the bottom of the profile. In this study there is a clear relationship between the occurrence of palygorskite and the development of the $\mathrm{Ck}$ horizon, suggesting that the environments of the secondary carbonate formations are favourable for palygorskite formation. The fact that palygorskite occurs at the textural boundary has been previously reported (Singer and Norrish 1974; Yaalon and Wieder 1976; Schwaighofer 1980). Palygorskite has not been detected in the upper horizons ( $\mathrm{Ap}, \mathrm{AB}$ and $\mathrm{Bk}$ ). Kaolinite present in these soils is incompatible with palygorskite and is considered to be detrital when present in such an assemblage. 
The proportion of amorphous silica in $\mathrm{Ck}$ horizons is high $\left(7 \cdot 8 \% \mathrm{SiO}_{2}\right.$ in the $<2 \mathrm{~mm}$ fraction and $10.03 \%$ in the clay fraction). This high proportion is consistent with the presence of cristobalite detected by X-ray diffraction. The concentration is also high in the clay fraction, and it is possible that it exists as gel. Soluble aluminium (Jackson 1969) is also present $(0 \cdot 18 \%$ in the $<2 \mathrm{~mm}$ fraction and $1.06 \%$ in the clay fraction).

The presence of cristobalite in sediments has been widely reported. This mineral can be of volcanic or pedogenic origin (Wilding et al. 1977). In these soils, it has formed under lacustrine conditions or during sedimentation; the latter is more probable according to its morphological characteristic. Its presence is very important, as it is responsible for the silica-rich environment. The presence of salts also has an important influence on palygorskite formation. These soils are situated in areas with medium rainfall $(460 \mathrm{~mm})$, and are only slightly saline (Table 3 ). The EC is $0.48 \mathrm{mS} \mathrm{cm}^{-1} ; \mathrm{Cl}^{-}$and $\mathrm{SO}_{4}^{2-}$ are the principal anions, and $\mathrm{Ca}^{2+}, \mathrm{Mg}^{2+}$ and $\mathrm{Na}^{+}$are the principal cations (Table 4).

The formation of palygorskite at textural discontinuities is typical in such soils (Singer 1984). The mineralogical composition suggests the alteration of smectite to palygorskte, as has been proposed by various studies (Yaalon and Wieder 1976; Abtahi 1977; Elprince et al. 1979; Martin de Vidales et al. 1987). An inverse palygorskite to smectite transformation has also been suggested (Bigham et al. 1980; Lee et al. 1983).

Weaver and Beck (1977) and Elprince et al. (1979) suggested that palygorskite stability is favoured over that of smectite by increases in the activities of either $\mathrm{Mg}, \mathrm{Si}$ or $\mathrm{pH}$. Thus, when palygorskite is being formed, smectite is dissolving, and vice versa.

All these data, together with palygorskite enrichment in the finest clay fraction and the presence of $\mathrm{Mg}^{2+}$ ions, suggest the possibility of authigenic palygorskite formation from smectite, but also suggest that palygorskite is dissolving while smectite is being formed.

Singer and Norrish (1974) have shown that at the concentration of silica normally found in soil solution, palygorskite would not be stable at $\mathrm{pH}$ values below $7 \cdot 7$ at high magnesium concentration, nor below pH 9 at lower magnesium levels. The $\mathrm{pH}$ of these soils is 7.6 and the magnesium in solution available for the formation of the mineral is very low, so the alteration of palygorskite to smectite is possible.

Under the present conditions of the soil, it is possible that this palygorskite is being transformed into smectite, and this could give rise either to the appearance of a small proportion of palygorskite in some $\mathrm{Ck}$ horizons, or to its absence.

The sporadic nucleation of large fibres of palygorskite on silica crystals suggests that the latter mineral could provide the necessary silicon for palygorskite formation, as has been indicated by Singer (1984).

\section{Summary}

Palygorskite present in the soils studied in this paper is associated with soil formation with textural discontinuities. Under the present conditions of these soils ( $\mathrm{pH}$, magnesium and silicon concentration and soluble salts), the alteration of palygorskite to smectite is suggested. 


\section{References}

Abtahi, Al. (1977). Effect of a saline and alkaline ground water on soil genesis in semi-arid southern Iran. Soil Sci. Soc. Am. J. 41, 583-8.

Bigham, J. M., Jaynes, W. T., and Allen, B. L. (1980). Pedogenic degradation of sepiolite and palygorskite on the Texas High Plains. Soil Sci. Soc. Am. J. 44, 159-67.

De Leenher, L., Van Ruymbeke, M., and Maes, L. (1965). The chain-hydrometer method for particle size analysis. Z. Pflanzenernähr. Düng Bodenk. 68, 10-19.

Elprince, A. M., Mashhady, A. S., and Aba-Husayn, M. M. (1979). The occurrence of pedogenic palygorskite (attapulgite) in Saudi Arabia. Soil Sci. (Moscow) 7, 154-60.

FAO (1988). 'Soils Map of the World.' Revised legend. (FAO: Rome.)

Galan, E. (1987). 'Industrial Applications of Sepiolite from Vallecas-Vicálvaro, Spain: A Review.' Proc. Int. Clay Conf. Denver 1985. (Eds L. G. Schultz et al.) (Clay Minerals Soc.: Bloomington, Indiana.)

Galan, E., and Castillo, A. (1984). Sepiolite-palygolskite in Spanish Tertiary Basins: Genetical patterns in continental environments. In 'Palygorskite-Sepiolite. Occurrence, Genesis and Uses. Developments in Sedimentology'. (Eds A. Singer and E. Galan.) pp. 87-125. (Elsevier: Amsterdam.)

Gonalez Garcia, F., and Perez Rodriguez, J. L. (1970). Constitución y propiedades fisicoquímicas de las arcillas de suelos del Valle del Guadalquivir. I. Tierras Negras Andaluzas (Vertisoles). Rendsinas y suelos pardo-calizos margosos vérticos (suelos margosos béticos). An. Edaf. Agrobiol. XXIX, 11-12, 791-820.

IGME (1975). Mapa Geológico de España. E. 1:50000. ECIJA. (Instituto Geológico de España: Madrid.)

Jackson, M. L. (1969). 'Soil Chemical Analysis, Advanced Course,' (Madison, Wisconsin.)

Lamouroux, M., Paquet, H., and Millot, G. (1973). Evolution des mineraux argileux dans les sols du Liban. Pedologie 13, 53-71.

Lee, S. Y., Dixon, J. B., and Aba-Husayn, M. M. (1983). Mineralogy of Saudi Arabian Soils. Eastern Region. Sọil Sci. Soc. Am. J. 47, 321-6.

Leguey, S., Martin de Vidales, J. L., and Casas, J. (1984). Diagenetic palygorskite in marginal detrital deposits located in the south of the Tertiary Duero Basin, Segovia, Spain. In 'Palygorskite-Sepiolite. Occurrence, Genesis and Uses. Developments in Sedimentology'. (Eds. A. Singer and E. Galan.) pp. 149-58. (Elsevier: Amsterdam.)

Lopez Galindo, A. (1987). Paligorskita en materiales cretácicos de la zona subbética. Bol. Soc. Esp. Miner. 10, 131-9.

Mackenzie, R. C. (1970). Simple phyllosicates based on gibbsite and brucite-like sheets. In 'Differential Thermal Analysis'. (Ed. R. C. MacKenzie.) pp. 498-534. (Academic Press: London.)

Mackenzie, R. C., Wilson, M. J., and Mashhady, A. S. (1984). Origin of palygorskite in some soils of the Arabian Peninsula. In 'Palygorskite-Sepiolite. Occurrence, Genesis and Uses. Developments in Sedimentology'. (Eds A. Singer and E. Galan.) pp. 177-86. (Elsevier: Amsterdam.)

McLean, S. A., Allen, B. L., and Craig, J. R. (1972). The occurrence of sepiolite and attapulgite in the Southern High Plains. Clays Clay Miner. 20, 143-219.

Martin de Vidales, J. L., Galvan, J., Arregui, M., and Jimenez Ballesta, R. (1987). Origen de Paligorskita, un modelo paleoedafodia-genético. Bol. Soc. Esp. Miner. 10, 44-5.

Martin Vivaldi, J. L., and Fenoll Hach-Ali, P. (1970). Palygorskites and sepiolites (Hormites). In 'Differential Thermal Analysis'. (Ed. R. C. MacKenzie.) pp. 553-71. (Academic Press: London.)

Millot, G., Paquet, H., and Ruellan, A. (1969). Neoformation de l'attapulgite dans les sols a carapaces calcaires de la Basse Moulonya (Maroc Oriental). C. R. Acad. Sci. Ser. D 268, $2771-4$.

Ruiz Cruz, M. D., Rodriguez Jimenez, P., and Carrasco, F. (1988). Genesis de paligorskita en sedimentos turbidíticos del campo de Gibraltar (S. W. de España). Bol. Soc. Esp. Miner. 11 , $46-7$.

Sanchez Camazano, M., and Garcia Rodriguez, A. (1971). Atapulgita y sepiolita en suelos sobre sedimentos calizos de Salamanca, España. An. Edajoe. Agrobiol. 30, 357-73. 
Sanchez Camazano, M., Garcia Rodriguez, A., and Forteza Bonnin, J. (1984). Sepiolita y paligorskjta en suelos de la comarca de Cerrato (Palencia). I. Congreso Nacional de la Ciencia del Suelo. Tomo II. Soc. Esp. Cienc. Suel, Madrid. 945-58.

Schwaighofer, A. (1980). Pedogenetischer palygorskit in einem lossprofil bei stillfried and der march (Niederosterreich). Clay Miner. 15, 283-4.

Shadfan, H., and Dixon, J. B. (1984). Occurrence of palygorskite in the soils and rocks of the Jordan Valley. In 'Palygorskite-Sepiolite. Occurrence, Genesis and Uses. Developments in Sedimentology. (Eds A. Singer and E. Galan.) pp. 187-98. (Elsevier: Amsterdam.)

Shadfan, H., Dixon, J. B., and Kippenberger, L. A. (1985). Palygorskite distribution in the Tertiary limestone and associated soil of northern Jordan. Soil Sci. 1, 206-12.

Singer, A. (1984). Pedogenic palygorskite in the arid environment. In "Palygorskite-Sepiolite. Occurrence, Genesis and Uses. Developments in Sedimentology'. (Eds A. Singer and E. Galan.) pp. 169-75. (Elsevier: Amsterdam.)

Singer, A., and Galan. E. (Eds) (1984). 'Palygorskite-Sepiolite. Occurrence, Genesis and Uses. Developments in Sedimentology.' (Elsevier: Amsterdam.)

Singer, A., and Norrish, K. (1974). Pedogenic palygorskite. Occurrences in Australia. Am. Mineral. 59, 508-17.

Weaver, C. E., and Beck, K. C. (1977). Miocene of the S.E. United States: a model for chemical sedimentation in peri-marine environment. Sediment. Geol. 17, 1-234.

Wilding, L. P.. Smeck, N. E., and Dress, L. R. (1977). Silica in soils. In 'Minerals in Soil Environments'. (Eds J. B. Dixon and S. B. Weed.) pp. 471-542. (Soil Sci. Soc. Am.: Madison, Wisconsin.)

Yaalon, D. M., and Wieder, M. (1976). Pedogenic palygorskite in some arid brown (calciorthid) soils of Israel. Clay Miner. 11, 73-80.

Zelazny, L. W., and Calhoun, F. G. (1977). Palygorskite (Atapulgite), sepiolite, talc, pyrophyllite and zeolites. In 'Minerals in Soil Environments'. (Eds S. B. Dixon and S. B. Weed.) pp. 435-70. (Soil Sci. Soc. Am.: Madison, Wisconsin.) 